Etnográfica

Revista do Centro em Rede de Investigação em

Antropologia

vol. $23(2) \mid 2019$

Vol. $23(2)$

\title{
Sobre a distância entre a "situação colonial" em Moçambique e o luso-tropicalismo: carta de António Rita Ferreira para Jorge Dias, com artigo anexo
}

On the distance between the "colonial situation" in Mozambique and the lusotropicalism: letter of António Rita Ferreira to Jorge Dias, with attached article

\section{Cláudia Castelo e Vera Marques Alves}

\section{OpenEdition}

\section{Journals}

Edição electrónica

URL: https://journals.openedition.org/etnografica/6964

DOI: 10.4000/etnografica.6964

ISSN: 2182-2891

\section{Editora}

Centro em Rede de Investigação em Antropologia

\section{Edição impressa}

Data de publição: 1 junho 2019

Paginação: 417-438

ISSN: 0873-6561

\section{Refêrencia eletrónica}

Cláudia Castelo e Vera Marques Alves, «Sobre a distância entre a "situação colonial" em Moçambique e o luso-tropicalismo: carta de António Rita Ferreira para Jorge Dias, com artigo anexo», Etnográfica [Online], vol. 23 (2) | 2019, posto online no dia 25 junho 2019, consultado o 19 janeiro 2022. URL: http://journals.openedition.org/etnografica/6964 ; DOI: https://doi.org/10.4000/etnografica.6964

\section{(c) (†) (8)}

Etnográfica is licensed under a Creative Commons Attribution-NonCommercial 4.0 International License. 


\section{Sobre a distância entre}

\section{a "situação colonial" em Moçambique e o luso-tropicalismo:}

carta de António Rita Ferreira

para Jorge Dias, com artigo anexo

\section{Cláudia Castelo e Vera Marques Alves}

Este in memoriam revela que num artigo que ficou inédito, enviado em carta a Jorge Dias, António Rita Ferreira criticou a falta de fundamentação sociológica do luso-tropicalismo em Moçambique. Acrescenta densidade à figura do antropólogo amador que ficou conhecido pela polémica com Marvin Harris, mostra a cumplicidade entre os dois antropólogos portugueses, não obstante os seus diferentes percursos e perspetivas, e confirma as potencialidades da correspondência privada enquanto fonte histórica.

PALAVRAS-CHAVE: antropólogos, colonialismo, correspondência, luso-tropicalismo, Moçambique.

On the distance between the "colonial situation" in Mozambique and the luso-tropicalism: letter of António Rita Ferreira to Jorge Dias, with attached article - This in memoriam reveals that in an unpublished article attached to a letter to Jorge Dias, António Rita Ferreira criticized the lack of sociological foundation of the luso-tropicalism in Mozambique. It adds density to the figure of the amateur anthropologist who became known for the controversy with Marvin Harris, unveils the complicity between the two Portuguese anthropologists, despite their different paths and perspectives, and confirms the potentialities of private correspondence as historical source.

KEYWORDS: anthropologists, colonialism, correspondence, luso-tropicalism, Mozambique.

CASTELO, Cláudia (claudiacastelo@ces.uc.pt) - Centro de Estudos Sociais, Universidade de Coimbra, Portugal.

ALVES, Vera Marques (vera.mmma@gmail.com) - Centro em Rede de Investigação em Antropologia (CRIA), Universidade de Coimbra, Portugal. 


\section{INTRODUÇÃO}

António Rita Ferreira (português, n. Mata de Lobos, 1922 - m. Bicesse, 2014), funcionário colonial e antropólogo e sociólogo autodidata, ${ }^{1}$ viveu em Moçambique desde os dois anos de idade até 1977.2 Ao conhecimento das realidades humanas, sociais e históricas desse território dedicou toda a sua obra, mas permanece um quase desconhecido no meio das ciências sociais portuguesas, apesar dos trabalhos de Rui Mateus Pereira, que há cerca de 30 anos tem vindo a destacar a singularidade do percurso de Rita Ferreira - "porventura o mais esclarecido etnógrafo dos tempos coloniais em Moçambique" (Pereira 2001) - e a qualidade imprevista da sua monografia etnográfica sobre os Zimba (Pereira 2016), elaborada no âmbito do concurso para administrador de circunscrição. Um capítulo da tese de doutoramento de Pereira (2005: 366-384) é dedicado a Rita Ferreira, "etnólogo do Governo" de Moçambique. Lorenzo Macagno $(1999,2015,2016)$ tem estudado a polémica entre Rita Ferreira e Marvin Harris - também estudada por Pereira (1986) -, a propósito do movimento migratório do Sul de Moçambique para a África do Sul, mas o seu enfoque incide no antropólogo norte-americano. Nuno Domingos (2013), por sua vez, também abordou alguns aspetos da obra de Rita Ferreira, analisando em particular a sua investigação sobre a condição e as possibilidades de enquadramento social da população africana na Lourenço Marques dos anos 60.

Caso ímpar de antropólogo amador (também no sentido afetivo) em Moçambique colonial e, até ver, no conjunto do império, a integração de Rita Ferreira numa história da antropologia portuguesa que extravase a antropologia académica poderá contribuir para uma visão mais abrangente e complexa da antropologia produzida nas colónias portuguesas na era da descolonização. De resto, como já defenderam vários autores (ver, por exemplo, Pels e Salemink 1994), a análise das práticas e dos discursos etnográficos que missionários, administradores e funcionários coloniais desenvolveram em locais e momentos históricos específicos é essencial a qualquer entendimento da relação entre a disciplina antropológica e o colonialismo. Só deste modo, como também sugeriu George Stocking, Jr. (1991: 5), se conseguirá explorar a efetiva variedade de formas de relacionamento entre a antropologia e o fenómeno colonial, evitando as generalizações simplistas que, tantas vezes, têm dominado o debate sobre o tema.

I Rita Ferreira ingressou na carreira administrativa depois de concluir o $7 .^{\circ}$ ano do liceu. No final da década de 1950 frequentou um curso de Estudos Bantus na Universidade de Pretória, sem, no entanto, obter qualquer grau académico.

2 Agradecemos ao Museu Nacional de Etnologia, por nos ter facultado o acesso à correspondência de António Rita Ferreira para Jorge Dias, e a Filipe e João Rita Ferreira, por nos terem autorizado a publicar a carta e o artigo de seu pai. 
Reveladora da atividade de Rita Ferreira no domínio da antropologia e da rede científica que foi tecendo, a sua correspondência com académicos portugueses e estrangeiros só parcialmente está disponível ao público no site "Casa Comum”, da Fundação Mário Soares. ${ }^{3}$ Parte significativa das cartas permanece na posse dos seus filhos, João e Filipe Rita Ferreira, sendo possível a consulta a pedido, através dos contactos disponibilizados no site "António Rita Ferreira". ${ }^{4}$ A sua correspondência ativa e passiva encontra-se inédita e apenas as missivas que trocou com Marvin Harris foram fonte de pesquisa. ${ }^{5}$

A carta que agora se publica faz parte do conjunto de cartas de Rita Ferreira para Jorge Dias existente no espólio do professor e antropólogo português no Museu Nacional de Etnologia, conjunto esse que Vera Marques Alves localizou e estudou no âmbito do projeto de investigação "Ciências de campo no terreno 'luso-tropical': conhecimento, ideologia, governo no império colonial português tardio", coordenado por Cláudia Castelo. ${ }^{6}$ A carta e o anexo foram transcritos por Cláudia Castelo e Alexandra Raimundo, com respeito pela grafia original, e são acompanhados por notas de rodapé pontuais que visam esclarecer informação subentendida no texto.

No verão de 1956, António Jorge Dias, à época professor ordinário do Instituto Superior de Estudos Ultramarinos (ISEU) e vogal do Centro de Estudos Políticos e Sociais (CEPS) da Junta das Missões Geográficas e de Investigações do Ultramar (JIU), visitou Moçambique pela primeira vez. O objetivo era proceder à "prospecção das minorias étnicas chinesa, maometana e indiana" e traçar um plano de trabalhos de campo para o triénio seguinte. ${ }^{7}$ Foi uma espécie de viagem exploratória, que antecedeu o lançamento da Missão de Estudo das Minorias Étnicas do Ultramar Português. Informado pelo tenente, e também antropólogo, Simões Alberto de que Jorge Dias queria "contactar com os indivíduos que na província se dedicavam a pesquisas sobre as populações nativas", assim como "travar conhecimento com os antropólogos sul-africanos”, Rita Ferreira convida-o para passar dois ou três dias em Sabie, Transvaal Oriental, União da África do Sul, onde exercia o cargo

3 Ver $<$ http://casacomum.org/cc/arquivos?set=e_9579\#!e_957 I > (última consulta em junho de 2019).

4 Ver < http://www.antoniorita-ferreira.com/pt/pagina-inicial > (última consulta em junho de 2019).

5 Lorenzo Macagno pôde fotocopiar parte do acervo de cartas pessoais de Rita Ferreira quando o entrevistou em 2012 (Macagno 2015: 84) e teve acesso às cartas trocadas com Marvin Harris depois da morte de Rita Ferreira (Macagno 2016: 3).

6 Todas as cartas citadas neste texto, incluindo a que aqui se publica, pertencem a esse espólio de António Jorge Dias existente no Museu Nacional de Etnologia (MNE), em Lisboa. A grafia original foi mantida em todos os trechos citados. O projeto referido foi desenvolvido no Centro Interuniversitário de História das Ciências e da Tecnologia, Universidade de Lisboa, e financiado pela Fundação para a Ciência e a Tecnologia (IF/00519/2013).

7 Ofício de Adriano Moreira, diretor do CEPS, para o presidente da Comissão Executiva da JMGIU, 2/5/1956 (Universidade de Lisboa, Arquivo Histórico do IICT, Comissão Executiva da JIU, processo 605, vol. 1, doc. n. ${ }^{\circ}$ 19). 
de administrador interino na Curadoria dos Negócios Indígenas. ${ }^{8}$ Por motivos que não apurámos, Dias não se encontrou com Rita Ferreira nessa ocasião. Um ano depois, Rita Ferreira escrevia: "Estou verdadeiramente ansioso por conhecer V. Ex.cia pessoalmente e, como antropólogos, conversarmos sobre certos aspectos sociológicos de Moçambique. A gravidade de certos problemas é verdadeiramente grande". ${ }^{9}$

No espólio de Dias encontram-se 21 cartas de Rita Ferreira, escritas entre 11 de julho de 1956 e 3 de janeiro de 1968, de Sabie, Beira e Lourenço Marques. Na correspondência transparece a relação franca e cordial que, desde cedo, ligou os dois antropólogos (a partir de 1958, a fórmula de despedida nas cartas é: "Afectuosamente"). Os assuntos mais tratados reportam-se aos trabalhos antropológicos e sociológicos de Rita Ferreira (de que envia cópias a Jorge Dias), à sua vontade de estudar e se formar em antropologia e se dedicar profissionalmente à investigação, às dificuldades que o seu projeto enfrentava, dada a sua condição de funcionário colonial, aos problemas na progressão na carreira (a baixa classificação no concurso para administrador de circunscrição) e ao excesso de trabalho burocrático, que o deixava "exausto", "física e mentalmente cansado" para pegar em trabalhos científicos quando chegava a casa. Várias cartas referem o trabalho realizado por Marvin Harris em Moçambique e a polémica com o antropólogo norte-americano na revista Africa sobre a questão do trabalho migratório de moçambicanos para a União da África do Sul. Há igualmente várias menções às vicissitudes da colaboração de Rita Ferreira com o Instituto de Investigação Científica de Moçambique (IICM) e a sua passagem para o Instituto do Trabalho. Numa carta escrita a 22 de junho de 1960, aborda um acontecimento marcante da história de Moçambique, o massacre de Mueda. Além da oferta de trabalhos e dos pedidos de comentário recíprocos, um aspeto a ressaltar prende-se com o empréstimo de bibliografia (a "Gramática do Mavia") e apontamentos (sobre o conceito de "tribo") e com recomendações metodológicas que Rita Ferreira oferece a Jorge Dias, quando este se preparava para fazer trabalho de campo junto dos Maconde:

"Permito-me recomendar-lhe não deixe de estudar, em primeiro lugar, os agregados políticos tradicionais. Entre outros, cometi esse grande erro no meu estudo sobre os Zimbas: só mais tarde compreendi que nenhum aspecto por mais simples que seja da cultura que estudamos tem significação enquanto não for colocado dentro da estrutura de uma instituição". ${ }^{10}$

10 Carta de A. Rita Ferreira a A. Jorge Dias, Beira, 14/8/1957. 
A última carta de Rita Ferreira que se encontra no espólio de Jorge Dias, escrita em papel timbrado do Instituto do Trabalho, informa que o IICM acaba de publicar o seu último trabalho "Os Cheuas de Moçambique", "remodelação e aumento da antiga monografia sobre os Azimba”, e que está a realizar um inquérito sociológico sobre a população africana de Lourenço Marques. ${ }^{11}$ Apesar do interesse desse inquérito, o que mais o apaixonava era o trabalho etnográfico em meio rural. Em entrevista a Cláudia Castelo, recorda que nos dois anos que passou na Macanga (1952-1953) "foi crescendo a convicção de que a antropologia cultural era o [seu] ideal" (Rita-Ferreira 2013). Numa carta a Dias, afirma que gostaria de voltar ao "mato" para se dedicar de novo à antropologia social. ${ }^{12}$

A escolha da carta que agora se publica na Etnográfica justifica-se por ser uma crítica ao luso-tropicalismo a partir de Moçambique, que vem acrescentar uma nova dimensão ao conhecimento de que dispúnhamos sobre a receção em Portugal à doutrina de Freyre (Castelo 1999). Na senda da leitura sociológica de Mário Pinto de Andrade (1955, sob o pseudónimo de Buanga Fele), a cujo texto poderá ter tido acesso (em 1954 esteve em Paris fazendo pesquisas bibliográficas na Sorbonne e no Museu do Homem), e antes da crítica histórica de Charles Boxer (1963), Rita Ferreira denunciou num artigo que juntou a esta carta e que ficara inédito, o desfasamento entre o luso-tropicalismo e a "situação colonial" em Moçambique, recorrendo ao conceito que Georges Balandier apresentou num artigo de $1951 .{ }^{13}$ A carta e o seu anexo refletem a apreciação lúcida que Rita Ferreira fazia da "situação colonial" moçambicana, enraizada e concreta, baseada num longo e diversificado contacto com o território e as populações ${ }^{14}$ e informada por leituras de obras de referência de cientistas sociais que trabalharam no sul do continente africano (sobre a influência dos trabalhos sobre migrações de Henri Junod e Isaac Schapera, ver Pereira 2005: 372 e 381), a que teve acesso em estadias em Paris e Londres (1949 e 1954) e pela assinatura de periódicos científicos em língua inglesa. O documento revela-nos factos pouco ou nada conhecidos: o ataque que jornalistas do Notícias (matutino de Lourenço Marques, criado em 1926, dirigido por Manuel Simões Vaz) lançaram a Jorge Dias pelas considerações críticas que

11 Carta de A. Rita Ferreira a A. Jorge Dias, Lourenço Marques, 3/1/1968.

12 Carta de A. Rita Ferreira a A. Jorge Dias, Lourenço Marques, 8/3/1960.

13 A "situação colonial", cujo papel na crítica à dominação colonial tem sido salientado, germinou do trabalho de Balandier na África ocidental francesa (ex. Balandier 1951). O autor preconiza uma abordagem sociológica da sociedade colonizada e da sociedade colonial no seu conjunto, formando um sistema, uma totalidade complexa, e tendo em vista captar o seu dinamismo e não a sua pureza (para uma revisitação do conceito, ver Saada 2002).

14 Enquanto funcionário do quadro administrativo, viveu em Mogincual (a sul da Ilha de Moçambique), Bárué, Morromeu, Quelimane, Ressano Garcia, Lioma (Gurué), Homoíne, Macanga (Tete), Sabie (trabalhadores do Sul de Moçambique emigrados na África do Sul), Beira e Lourenço Marques. 
teceu sobre o comportamento dos colonos portugueses em Moçambique face aos africanos, na conferência "Contactos de cultura" (Dias 1958), realizada no âmbito dos Colóquios de Política Ultramarina Internacionalmente Relevante, no CEPS, no início de 1958, e a eventual censura (oficial ou interna) ao artigo que Rita Ferreira enviou àquele jornal procurando mostrar "a veracidade" das afirmações de Dias. ${ }^{15}$ Contudo, Rita Ferreira também não se coibiu de contestar, com elevação e estima, a visão do professor e amigo que, como já tem sido demonstrado (Macagno 2002; Pereira 2005), considerava que a miscigenação, a fraternidade cristã e a ausência de etnocentrismo eram traços essenciais, que se mantinham através dos séculos, do "carácter nacional" português (Sobral 2007: 495). E os exemplos em sentido contrário eram, como para Gilberto Freyre, desvios à tradição portuguesa, fruto da influência dos padrões sul-africanos. Por seu turno, Rita Ferreira não comungava da ideia de que a "personalidade-base" do português fazia dele um colonizador excecional. Daí que afirmasse:

"Pode ser que tenha sido excelente colonizador há séculos, quando a cultura ocidental não se achava tão impregnada por factores económicos como hoje em dia. Mas hoje é um péssimo colonizador, o único que em toda a África ainda usa e abusa dessas duas chagas do colonialismo: o trabalho forçado e os castigos corporais". ${ }^{16}$

Até 1959, os chefes de posto podiam, por delegação do administrador de circunscrição, aplicar castigos corporais aos "indígenas" (Castelo 2007: 298) e o trabalho forçado só seria abolido em 1961 com o fim do estatuto do indigenato. Colocamos a hipótese de Rita Ferreira ter tido conhecimento do relatório secreto que o inspetor superior de Negócios Indígenas, Henrique Galvão, apresentou à Comissão das Colónias da Assembleia Nacional em 1947, sobre as questões laborais em Angola. Relativamente a São Tomé, a sua experiência direta como comissário ad hoc encarregado de acompanhar o transporte de contratados de Moçambique para as roças de cacau terá sido decisiva na sua perceção da iniquidade do Estado Novo e do colonialismo português (Rita-Ferreira 2013). Assim, o luso-tropicalismo e a formulação que Jorge Dias apresentou na comunicação no CEPS - "tradição de colonialismo missionário" - tinham, segundo Rita Ferreira, "função de mito em todo o sistema colonial português"

15 Em entrevista a Cláudia Castelo, Rita Ferreira contou que "António Rosado, Nuno Bermudes, Guilherme de Melo e até Vasco de Matos Sequeira juntaram-se para humilharem o conhecido catedrático. Por ser amigo pessoal de Jorge Dias, procurei rebater os assomos escarninhos que esses jornalistas tinham empregado. Daí ter escrito em sua defesa 'Jorge Dias e a conjuntura sociológica moçambicana'. Este artigo também não foi aceite pela censura. Jorge Dias confessou-me o grande desgosto que sofrera com as grosserias e chacotas que lhe foram dirigidas" (Rita-Ferreira 2013: 12).

16 Carta de A. Rita Ferreira a A. Jorge Dias, Beira, 22/4/1958. 
e constituíam "cómodas racionalizações para os teóricos metropolitanos". Os teóricos coloniais, autores da reação indignada e violenta contra Jorge Dias no Notícias de Lourenço Marques, esses não subscreviam a apologia da mestiçagem e da interpenetração de culturas. António Rosado dirige jocosamente o convite "ao sr. Dr. Jorge Dias e outros portugueses da sua rija têmpera para proceder ao aumento da população mista no Ultramar", embora lhe bastasse viver algum tempo em Moçambique para "chegar à conclusão de que é possível viver em paz e harmonia com a raça negra, sem necessidade de a estragar com os defeitos da raça europeia". Para o articulista do Notícias, o europeu de Moçambique não tinha aversão pelo negro nem o tratava de forma desumana; a distância entre eles era "imposta pela civilização, pela cultura, pelos hábitos, pelas sensibilidades que facilmente perderá a razão de ser quando os africanos de cor atingirem o nível dos europeus". ${ }^{17}$ Como se mostrou alhures, em Portugal houve resistências a aspetos fundamentais do luso-tropicalismo e apenas uma versão "nacionalizada" da doutrina freyriana serviu de álibi à política externa e à propaganda do Estado Novo na era da descolonização (Castelo 1999, 2017). $\mathrm{O}$ documento que agora se publica revela que o luso-tropicalismo foi rejeitado em Moçambique, tanto por intelectuais que escreviam na imprensa diária como por um funcionário colonial "esclarecido" e dedicado à antropologia. Porém, os motivos da rejeição não podiam ser mais divergentes.

17 A. Rosado, “Temas e critérios - Reposta à letra: será despeito ou o Sr. Dr. não terá visto bem?...", Notícias, 15/3/1958, pp. 1 e 8. 
Carta de António Rita Ferreira a Jorge Dias

A. Rita Ferreira

C.P. 565

Beira

22 de Abril de 1958

Amigo e Sr. Prof.

Muito agradeço a sua carta de 24 do mês findo. A lufa-lufa do serviço e a preparação duma "recapitulação" da classificação e agrupamento étnicos de Moçambique, impediram-me que lhe respondesse há mais tempo. A situação do Quadro Administrativo a respeito de pessoal é cada vez mais angustiosa: não há quem queira ser aspirante. O resultado é que tenho de passar o dia a fazer serviço de dactilógrafo e outro serviço puramente mecânico, que me deixa arrasado.

Escrevi sobre a sua comunicação e a estúpida reacção local, o artigo que lhe mando. O "Notícias", onde costumo colaborar, não o publicou. Ignoro se por censura interna se por censura oficial.

Creio ter sido, contudo, bastante cauteloso no que escrevi. Se permite que lhe dê a minha opinião, quer parecer-me, pelas referências que li, que o Sr. Prof., impedido como se encontrava de tratar o assunto com a necessária independência devido à posição oficial que ocupa, se viu constrangido a concentrar a sua atenção em aspectos de somenos significação sociológica e a responsabilizar os europeus de Moçambique pela situação que existe. Eu, à base do conhecimento do meio moçambicano que tenho e do que sei que acontece em Angola e S. Tomé, sou, aqui para nós, um tanto mais ousado. Ponho em causa as virtudes do português como colonizador no mundo moderno. Pode ser que tenha sido excelente colonizador há séculos, quando a cultura ocidental se não achava impregnada por factores económicos como 
hoje em dia. Mas hoje é um péssimo colonizador, o único que em toda a África ainda usa e abusa dessas duas chagas do colonialismo: o trabalho forçado e os castigos corporais. O colonizador português conseguiu criar pelo menos nas três "províncias" que conheço estruturas político-económico-sociais que não podem passar sem o emprego destes dois meios de opressão. Em Angola, a situação do trabalho forçado ainda é pior (mas mais bem organizada) do que em Moçambique: aí o número de negros a distribuir por cada agricultor é fixado pelos próprios Negócios Indígenas e os administradores têm que os fornecer. E em S. Tomé vi os próprios administradores das roças empregarem castigos corporais. Em face destas e doutras cruéis realidade[s], creio que o "luso-tropicalismo" ou outras frases como a que citou de "tradição de colonialismo missionário" têm funções de mito em todo o sistema colonial português e constituem cómodas racionalizações para os teóricos metropolitanos. Estou certo que a elas recorreu para poder chamar a atenção dos responsáveis pela governança, sem que corresse o risco inútil e inglório de ser por eles considerado com desconfiança.

A "situação colonial" portuguesa pode ser definida como o faz George Balandier em relação a todas as "situações coloniais", mas com essas características não atenuadas, como se diz, pela "brandura dos nossos costumes" ou pelas nossas "ten[d]ências atávicas de assimiladores", mas exacerbadas pelo nosso atrazo económico, pela nossa irrascibilidade, pela sub-instrução e sub-educação do povinho humilde de onde sai a grande massa dos colonizadores. Oh, senhores, não poder escrever eu livremente sobre as amargas experiências dum homem colonial! O que se passou em mim naquela noite em S. Tomé em que fui insultado pelo administrador da roça onde estava hospedado por ter "ousado" ouvir sem a sua augusta presença as humildes queixas dos cabo-verdianos, angolanos e moçambicanos ali trabalhando em regime compelido. Talvez um dia o faça, já no fim da carreira, e que golpe não vai ser para os teóricos! Um golpe tão grande como vai ser o vibrado pelo trabalho do Prof. Marvin Harris. ${ }^{18}$

18 O resultado do trabalho de campo de Marvin Harris seria publicado em 1959 e daria azo à polémica entre Rita Ferreira e o antropólogo norte-americano a que fizemos referência acima (ver Harris 1959; Macagno 1999, 2015, 2016; Pereira 1986). 
$\mathrm{Na}$ "situação colonial" portuguesa há algo que "ne marche pas". Como explicar essas fugas em massa de trabalhadores, de famílias, de tribos para os territórios vizinhos, na Guiné, em Angola, em Moçambique. Só não fogem de S. Tomé por ser uma ilha! Ainda lendo recentemente o trabalho do Prof. Clyde Mitchell sobre os Ajauas da Niassalândia ${ }^{19}$ (para onde, como sabe, emigraram centenas de milhares, talvez algo como um milhão de indígenas de Moçambique) notei sem surpresa a informação de que todos aqueles que interrogou alegaram como motivo de abandono da terra natal, os maus tratos.

$\mathrm{Na}$ Federação segundo as últimas estatísticas, há nada menos do que 133.000 trabalhadores activos do sexo masculino de proveniência moçambicana. E na União 150.000. Isto junto aos do Tanganica, perfazem, como vê, quase metade dos homens válidos de Moçambique. E bestificamente, continuamos a dizer (como na recente e saborosa discussão do Plano de Fomento no Conselho Legislativo, quando se falou de mão de obra) que o indígena é preguiçoso e que só por meio de preparação psicológica se pode levar ao trabalho...

A misceginação também tem que se lhe diga. Há milhares de crianças mistas abandonadas pelos pais. E isto é tanto mais notável quanto é certo que no Congo Belga os pais das crianças mistas ilegítimas são sistematicamente chamados à responsabilidade...

Sobre a assimilação nem é bom falar.

Poucos são os que têm a coragem de aludir a esta situação catastrófica. E o Sr. Prof. foi um desses, embora sob evidentes constrangimentos psicológicos. Nós, os que vemos a situação com certa lucidez, não devemos, realmente, fugir. É preciso que fiquemos, para que possamos analisar, estudar (e, como sabe, ser um dia escutados) o ambiente sociológico que nos cerca. Temos uma tarefa a cumprir.

Os hábitos e pontos de vista locais estão tão empedernidos que me parece só por pressão do Governo Central poderem ser alterados. Quando digo locais, refiro-me também a S. Tomé e Angola. Mas não

19 Clyde Mitchell foi um antropólogo e sociólogo britânico que ajudou a fundar o Rhodes-Livingston Institute, na Rodésia do Norte (Zâmbia). Influenciado por Max Gluckman viria a transferir-se para a Universidade de Manchester. Rita Ferreira alude ao seu livro The Yao Village: A Study in the Social Structure of a Malawian Tribe (Mitchell 1956). 
terá a Metrópole receio de reacções locais de carácter separatista, se quiser pôr em prática certas medidas? É o que me parece que está acontecendo com o problema da mão de obra, por exemplo. Se se pusesse em prática as determinações legais, as repercussões económicas seriam extremamente graves e daí a revolta contra o Governo Central.

Permito-me aconselhá-lo a rodear a sua próxima visita do maior sigilo, pois me constou haver alguns elementos em Lourenço Marques que aguardam a sua vinda para se manifestarem contra si. É realmente lamentável, estúpida e incoerente e própria de ignorantões, a reacção desencadeada pela sua comunicação.

Desculpe esta carta ir um pouco atabalhoada. Tive que a interromper a todo o momento para atender a assuntos de serviço e um deles bem irritante: um dos aspirantes vai de urgência para a metrópole e com esta partida agrava-se a acumulação do expediente. O curioso da situação é que conheço tantos indígenas excelentes dactilógrafos, que andam miseravelmente de porta em porta procurando emprego por salários irrisórios! Aqui há dias, como se aceitam aspirantes, interinos, com a $4 .^{\text {a }}$ classe, um assimilado requereu a sua admissão. Pois foi por aqui uma risota gostosa. Até já pretos há no quadro administrativo, diziam, em grandes galhofas! A situação dos assimilados e mistos é muito angustiosa em face da legislação de salários mínimos e outras regalias, porque ninguém está disposto a dar-lhes os mesmos salários e direitos que se dão aos europeus. Enfim, problemas e mais problemas. A vantagem deste quadro é estarmos em contacto directo com eles.

Muito afectuosamente,

[assinatura] 


\section{Jorge Dias}

\section{e a conjuntura sociológica moçambicana}

Ainda não nos foi possível tomar conhecimento do texto completo da conferência proferida pelo Prof. Jorge Dias no Centro de Estudos Políticos e Sociais. Por isso, é a medo e baseados apenas nas citações com que deparámos nos artigos publicados na imprensa que decidimos tecer estes comentários. Mas antes, permitam-nos os homens de letras que subscreveram esses artigos que exprimamos a nossa mágoa pelas graçolas e insultos que não souberam reprimir. Quando, em meados do ano findo, nos foi dado conhecer pessoalmente Jorge Dias, logo nos seduziu a sua extrema modéstia e afabilidade, a sua superior lucidez e preparação. Doutorado por uma universidade alemã, com vários anos de permanência em diversos países estrangeiros, autor de obras de projecção internacional no campo da etnologia e da sociologia, é a antítese da imagem anedótica do catedrático pomposo e com hábitos de arrogância intelectual que nos dá A. Rosado. ${ }^{20}$ É, acima de tudo, um cientista social, ansiando que o deixem investigar em sossego e em detalhe. Nem nos parece que procure conquistar auriflamas, sinecuras ou magnificências. É provável que algumas das suas conclusões (falível como é a sociologia na elaboração de leis precisas) sejam menos exactas; mas decerto que não é com remoques galhofeiros e ofensivos que devem ser contestadas.

Se bem compreendemos, fez, na sua comunicação, uma tentativa para formular (como já o havia feito em relação à cultura portuguesa em outra comunicação apresentada no I Colóquio Internacional de Estudos Luso-Brasileiros, realizado em Washington em 1950) a personalidade base do europeu em Moçambique. A nós mesmo havia já ocorrido o interesse de tal tarefa, assim que travámos conhecimento com os trabalhos de Kardiner e Linton; ${ }^{21}$ tínhamos até tomado sobre o assunto alguns ligeiros e dispersos apontamentos.

20 Refere-se ao texto citado de A. Rosado, “Temas e critérios - Reposta à letra: será despeito ou o Sr. Dr. não terá visto bem?...", Notícias, 15/3/1958, pp. 1 e 8.

21 O psicanalista Abram Kardiner e o antropólogo Ralph Linton publicaram, em 1939, The Individual and His Society: the Psychodynamics of Primitive Social Organization, onde expuseram o conceito de "estrutura básica de personalidade" (Kardiner e Linton 1939). 
Mas primeiro convém, talvez, elucidar o leitor interessado nestes problemas o que deve entender-se por personalidade base dum povo. Trata-se de um conceito sociológico recente que corresponde ao antigo carácter nacional. Pode definir-se como "uma configuração psicológica particular, própria aos membros duma sociedade dada, e que se manifesta por um certo estilo de vida, sobre o qual os indivíduos tecem as suas variantes singulares". É a base da personalidade para os membros do grupo, é a matriz na qual se desenvolvem os traços do carácter. A noção não é nova, o que é nova é a significação que lhe é conferida: não é somente uma abstracção psicológica, mas um meio de pensar qualquer cultura como um todo, definindo-se cultura, de harmonia com Linton, como "a configuração geral dos comportamentos adquiridos e dos seus resultados, cujos elementos são adaptados e transmitidos pelos membros de uma sociedade dada". ${ }^{22}$ Para compreender uma cultura, não basta, pois, acumular informações sobre as instituições; é indispensável extrair o sentido dessas informações. Depois de utilizar esta noção e os seus métodos no estudo de várias culturas ditas "primitivas", o psicólogo americano Kardiner, baseado num inquérito sociológico profundo realizado por J. West num aglomerado meio rural, meio urbano do Middle-West estado-unidense, demonstrou que essa noção e esses métodos podem ser aplicáveis ao estudo das sociedades modernas ditas “civilizadas". ${ }^{23}$ Foi o que tentou fazer Jorge Dias em relação à "situação colonial” moçambicana.

Esta expressão, proposta por George Balandier, ${ }^{24} \mathrm{fez}$, decerto, franzir o sobrolho de alguns leitores. Mas nela não se devem ver quaisquer implicações políticas ou ideológicas; com ela, este sociólogo francês pretendeu classificar um tipo sui generis de sociedade criado pela instalação de civilizações complexas, de base técnica e economia desenvolvida, entre civilizações simples do tipo "primitivo", pré-mecânico, com uma economia de subsistência, numa relação de dominação-subordinação a que se encontram associados complexos problemas económicos, políticos, sociais e raciais e donde derivam, com facilidade, tensões e conflitos. A “situação colonial” cria grupos heterogéneos, de fundamento racial, mantendo frequentemente relações antagónicas, mas coexistindo num quadro político único.

Uma minoria numérica (mas não sociológica), animada por uma convicção de superioridade, age política, económica e espiritualmente sobre os seus autoctones com um vigor desproporcionado ao seu número. Tende a considerar

22 Linton (1945: 21).

23 Referência ao inquérito realizado por James West, pseudónimo de Carl Withers, em Plainville, uma pequena cidade nas montanhas Ozarks, no Missouri, que permitiu a Kardiner aprofundar o conceito de "estrutura básica de personalidade" (Kardiner at al. 1945).

24 Balandier (1951). 
a maioria aborígene como instrumento criador de riquezas, e tende a tornar-se, com o decorrer do tempo, tanto mais renitente à fusão quanto mais ameaçada se sente pela pressão demográfica e, portanto, receosa de ver a hierarquia estabelecer-se unicamente em função do critério numérico. Por estas e por outras razões, a integração social e económica dos aborígenes no seio do grupo dominante manifesta-se em extremo custosa. Esse grupo apresenta-se como modelo, mas, na prática, não facilita os meios capazes de realizá-lo. Esta complexa situação repousa também sobre ideologias, sobre um sistema de justificações e racionalizações que, de um modo geral, afirmam a incapacidade e o retardo do autoctone, a superioridade cultural do colonizador e o direito e dever que lhe assiste de proceder como procede. Ao grupo colonizado falta, por sua vez, coesão; encontra-se dividido étnica e linguisticamente, dividido espiritualmente, dividido socialmente pela acção administrativa e económica, e constitui um terreno onde se entrechocam crises e desajustamentos. O colonizado adquire assim uma psicologia própria que o psicólogo francês O. Mannoni classificou de "dependente" e apresenta conflitos internos de "homem marginal", que vê duramente atingido o equilíbrio das organizações socio-culturais a que tradicionalmente pertencia. ${ }^{25}$

A “situação colonial” é, deste modo, em extremo complexa e, para ser compreendida na sua totalidade, é necessária a contribuição simultânea de historiadores da colonização, de economistas, de políticos e administradores, de sociólogos (interessados nas relações entre civilizações estranhas), de antropólogos (interessados nas culturas tradicionais nativas e suas mutações), de psicólogos (interessados nas relações raciais).

Resumidas as características, segundo George Balandier, comuns a todas as "situações coloniais" do planeta, incluídas as das vizinhas União da África do Sul e Federação das Rodésias, há algo de específico a acrescentar para compreendermos na sua totalidade o fenómeno moçambicano. O grupo dominante é proveniente de um país pequeno, escassamente dotado de riquezas naturais, de limitado desenvolvimento económico e industrial, com uma população de baixo rendimento per capita e, na maioria, de extracção rural. Nos meios intelectuais, desde cedo se desenvolveu, baseada em vasta experiência colonizadora, uma ideologia de integração racial. Este povo, pela primeira vez na sua história, aplica a sua capacidade colonizadora lado a lado com povos europeus de diferente extracção cultural e racial, provenientes de metrópoles altamente industrializadas e de forte desenvolvimento económico. A fronteira, além de ser, devido a circunstâncias históricas, extensa e traçada sem consideração pela divisão étnica

25 Refere-se à obra do psicanalista francês Octave Mannoni, Psychologie de la Colonisation (Mannoni 1950). 
autoctone, permite múltiplas e fáceis simbioses. Finalmente, peculiaridades geográficas impõem relações de certa constância e intensidade com os estrangeiros, com repercussões economicamente vantajosas.

Fica assim, exposta, em traços largos, a noção que Jorge Dias pretendeu aplicar a uma situação sociológica peculiar. Para resolução dos complexos problemas por ela levantados, são muitos autores de opinião que o colonizador lusitano encontrou soluções sólidas e verídicas por meio de uma intensa misceginação racial e cultural que, com o decorrer do tempo, produz perfeita integração social e económica. Um dos próceres desta doutrina, o sociólogo brazileiro Gilberto Freyre, deu-lhe o nome de "luso-tropicalismo". ${ }^{26}$

Até que ponto os princípios do "luso-tropicalismo" têm sido realizados em Moçambique?

Como intróito pessoal cremos necessário precisar que nos é inaplicável qualquer acusação de desconhecimento do meio. Não pesam apenas sobre nós quase quatro décadas vividas entre a "situação colonial" moçambicana, mas, principalmente, mais de três lustros vividos de Norte a Sul, por imposições profissionais, no âmago desta situação.

Passando agora propriamente ao conteúdo da comunicação, cremos que o ilustre catedrático não deixou de considerar na sua definição de personalidade base do europeu português de Moçambique, que este, além de constituir o grosso do grupo económica, política e espiritualmente dominante, numa sociedade de tipo "colonial”, participa também numa sociedade global, e, como tal, é ponto de convergência de todo um complexo de problemas levantados por aquela conjuntura sociológica específica. Todavia, neste ponto, parece-nos conveniente fazer a distinção (que ignoramos se Jorge Dias fez) entre as facetas dessa personalidade que não provocam quaisquer repercussões sobre (nem derivam da) estrutura da sociedade "colonial", e aquelas que são condicionadas por ela. As primeiras nos parecem, salvo o devido respeito, desprovidas de importância.

Vejamos, por exemplo, as considerações que tece sobre certos hábitos lúdicos. Se considerarmos como típico da cultura portuguesa o facto de camponesas só conhecerem o idioma pátrio e não fumarem, e o facto de rústicos beberem

26 O conceito foi cunhado durante a visita oficial de Freyre a Portugal e às colónias portuguesas (Freyre 1953), embora já estivesse em gestação desde Casa-Grande \& Senzala (Freyre 1933). Em traços gerais, o luso-tropicalismo postula a especial capacidade de adaptação dos portugueses aos trópicos, não por interesse político ou económico, mas por empatia inata e criadora. A aptidão do português para se relacionar com as terras e gentes tropicais, a sua plasticidade intrínseca, resultaria da sua própria origem étnica híbrida, da sua "bi-continentalidade" e do longo contacto com mouros e judeus na Península Ibérica, nos primeiros séculos da nacionalidade, manifestando-se sobretudo através da miscigenação e da interpenetração de culturas. 
carrascão e bailarem em romarias, estamos, sem dúvida, perante desvios dessa cultura quando mulheres portuguesas gostam de tabaco e falam inglês, e quando homens portugueses bebem whisky e dançam em boites. Onde cremos que Jorge Dias se engana é quando julga que esses procedimentos desviantes se adoptam por serem de "bom tom", expressão que tem latente a ideia de insinceridade. A nós antes nos quer parecer que se seguem por serem mais úteis ou mais agradáveis; a mulher que fuma, como o homem que bebe whisky, não o fazem rilhando os dentes, para impressionar o próximo com o seu refinamento ou para ganhar auréola de "modernos", mas porque sentem intenso prazer nisso. Não vemos que esses hábitos tenham qualquer significação sociológica, além de traduzirem um fenómeno de difusão, de resto, também observável entre certos meios metropolitanos.

E quanto à mulher? Será que, na realidade, Jorge Dias generalizou em demasia as suas observações? Não podemos negar que existe o tipo que define como ocioso, deficientemente preparado e possuíndo ideais de luxo e de vida fácil. Mas esse tipo, tanto quanto vemos, encontra-se quase exclusivamente na classe mais elevada da pirâmide social (a divisão do grupo dominante em classes é uma realidade que não pode passar despercebida à atenção do sociólogo). Na classe média e entre o proletariado, recorre-se ao emprego feminino em larga escala. Sintomático nos parece o desaparecimento quase total do tipo clássico de filha-família que aguarda passivamente que surja um marido e se vai, entretanto, esmerando em prendas domésticas. Segundo se nos afigura, o ideal de muitos pais está em dar a suas filhas uma instrução tal que lhes permita a obtenção de empregos remuneradores em que ganhem a vida sem apoio e possuam, ulteriormente, se tal for necessário, contribuir para a economia do lar que formarem.

(Sobre a mulher "colonial" diga-se, a propósito, que há algo de interessante a estudar e que não escapou à penetração de O. Mannoni, isto é, as causas psicológicas profundas que a levam a assumir, em relação aos grupos dominados, atitudes mais ríspidas e intolerantes).

Encarando-as à luz da nossa experiência, cremos ter o conferencista discernido e enunciado com precisão e veracidade algumas das facetas condicionadas pelo fenómeno "colonial" na personalidade base do europeu português de Moçambique, embora, na sua maioria, se bem compreendemos, sejam típicas de qualquer agrupamento dominante numa sociedade de tipo idêntico.

Mas antes de começar, permita-nos o ilustre conferencista que manifestemos as nossas reservas quanto ao que definem como "tradição de colonialismo missionário", noção que lhe serviu de base para concretizar os desvios patentes em Moçambique. Quereria referir-se ao "luso-tropicalismo"? Salvo o devido respeito, aquela noção, embora de forte conteúdo emotivo, parece-nos em extremo vaga e filia-se, quiçá, nas racionalizações que contribuem para dar à "situação 
colonial" o seu carácter de inautenticidade. Também aqui convém frisar que a ruptura entre as fórmulas ideológicas do tipo "missão e responsabilidade colonizadora" e as práticas sociais, é característica de toda a "situação colonial" e não apenas de Moçambique.

Reflitamos que, com excepção de alguns idealistas, a totalidade dos emigrantes, mesmo os de formação universitária, não vão propagar ou dar aplicação a elevados princípios teóricos sobre colonização, mas, muito comezinhamente, melhorar a sua posição económica e social. Não hesitam, naturalmente, em tirar proveito duma situação sociológica peculiar que lhes fornece meios para atingirem o seu fim assaz rapidamente e com o menor esforço possível. No caso lusitano acontece que, em grande parte, são provenientes de camadas sub-instruídas, economicamente débeis e de inferior estatuto social. Desembarcam com a energia própria do desapossado, liberto de controlos internos e disposto a tudo para enriquecer. Com mimetismo atávico, logo aderem a certas atitudes etnocêntricas com que deparam. Por outro lado, vendo-se repentinamente transformados em membros dum grupo estratificado, mas onde há (por muito que custe aos contraditores do conferencista) um sentimento colectivo de superioridade rácica e cultural, natural parece que tendam a assumir comportamentos de "compensação por vaidade", que procurem marcas externas de prestígio e, sobretudo, excessivo respeito e obediência por parte do grupo dominado. Mas sociologicamente mais importantes que as desforras psicológicas à custa das quais esses elementos procuram sentir-se superiores, se afiguram os extremos a que (de parceria com muitos não europeus, sobretudo asiáticos) se deixam arrastar numa ânsia de conforto e de segurança económica, que nunca conheceram, e de acumulação de pecúnia, que nunca tiveram. Esse dinâmico impulso conduz, facilmente, a hábitos de canibalismo económico e de exploração do homem pelo homem, de que o aborígene é principal vítima, testemunha e crítico.

Seja, porém, como for, há uma consequência proveniente dessa imigração pouco qualificada e de nula capacidade económica - que é que, inserindo-se como se insere no seio duma "situação colonial" típica, constitui o mais forte obstáculo à ascenção e à integração económica dos autoctones evoluídos. Tenhamos sempre presente este aspecto vital: por assimilação, os aborígenes entendem, não a assimilação puramente jurídica, mas principalmente e acima de tudo, a assimilação económica, social e de níveis de vida. Assim, se o virmos à luz deste critério, antolha-se-nos que o sistema de assimilação tem, em Moçambique, aspectos de singular inoperância: o número de beneficiados é sociologicamente desprezável e aumenta numa percentagem menor do que a que se verifica em relação ao total da população indígena; a sua integração social e económica é em extremo custosa. Além disso, a sua existência está a provocar uma confusão curiosa entre estatutos jurídicos e situações sociais concretas. (Talvez esta difícil 
questão da assimilação revele em Moçambique, juntamente com outras, a existência do mesmo conflito que acontecimentos recentes permitiram e permitem discernir em certas colónias de povoamento como a Argélia, o Quénia e as Rodésias: o conflito entre a administração central que visa garantir certos direitos ao colonizado e os colonos que visam cerceá-los).

Outro aspecto temos de aceitar como típico da "situação colonial" moçambicana: um desinteresse quase geral e absoluto pelos valores e pela vida nativa. O contacto encontra-se reduzido ao mínimo; o grupo dominante vive divorciado das realidades sociológicas. Mesmo entre os meios intelectuais (mais responsáveis por conseguinte) há um sector importante que gasta o seu talento em subtilezas nefelibatas e ignora o ambiente que o cerca. Também, a nosso ver, estão a condicionar-se defeituosamente as novas gerações. A juventude desde a mais tenra infância que, nos lares, depara com concepções e hábitos etnocêntricos petrificados, aprende a aceitar o carácter instrumental do aborígene, e se compenetra de que faz parte de uma aristocracia pigmentária. O condicionamento oficial faz alguns esforços para remediar estes males, mas, dum modo geral, não nos parece adaptado a sincronizar os educandos com o ambiente, a prepará-los para uma sociedade pluriracial e integrada.

Baseados em inúmeros exemplos com que temos deparado no decurso da existência, mantemos a opinião de que existe, de modo latente e pronto a manifestar-se com virulência, certa discriminação de fundamento racial. Outros, mais respeitáveis e experientes do que nós, afirmam tal não ser verdade. Uma certeza neste controvertido campo não está fora das possibilidades da moderna sociologia. Naturalmente que quem sente os efeitos da existência das práticas discriminatórias não são os membros do grupo leucoderme e, desse modo, só inquéritos sistemáticos realizados entre a população melanoderme, sobretudo negra, permitiriam relegar para o plano de inofensiva "conversa de café" as actuais divergências de opinião.

Referiu-se Jorge Dias a certos tratamentos coercivos e desumanos. Este, quer-nos parecer, é um dos aspectos mais singulares e melindrosos da nossa colonização, e ressalta, sobretudo, quando se acham em causa questões de prestígio pessoal e de interesse económico. Os psicólogos talvez o possam explicar por uma composição temperamental peculiar. Qual de entre nós, na verdade, é capaz de reprimir gestos irrascíveis e palavras humilhantes ou ofensivas quando em estado de exaltação contra o aborígene? E estas condutas descontroladas são tanto mais para lamentar quanto é certo que estrangeiros seguindo políticas de confessada segregação se revelam singularmente afáveis nos contactos de indivíduo com indivíduo. Fleuma? Tradições seculares de respeito pelo indivíduo? Também aqui só a psicologia pode dar uma resposta satisfatória. Quiçá estreitamente relacionado com esta faceta da nossa personalidade de "coloniais" e com 
desníveis de desenvolvimento económico estão certas condutas muito típicas de escape, individual ou em grupos organizados, que não raro assumem vastas proporções e dão origem a consideráveis repercussões políticas, sociais e económicas.

Procurar na misceginação em grande escala uma solução para todos estes problemas parece-nos, salvo o devido respeito, utópico e inoperante. Começa por ser modernamente impraticável: pôde fazer-se nos tempos de comunicações difíceis, quando a emigração era sobretudo masculina e as colónias terreno bravio e inóspito que as mulheres temiam e onde os companheiros não queriam arriscá-las. Ora as condições são hoje totalmente diferentes: a população europeia feminina tende a igualar em número a masculina e, portanto, a fazer valer os seus direitos. E, por muito que isso custe a admitir aos corifeus do "luso-tropicalismo", o português, na escolha da consorte legítima, manifesta decidida preferência pelas mulheres do seu próprio extracto racial. Cremos que o colonizador português nunca aplicou em Moçambique, em escala sociologicamente significativa, o "método Albuquerque", celebrado por Gilberto Freyre pela excelência dos resultados a que conduziu no Brazil, dos séc. XVI a XIX, isto é, o genearca, difusor cultural e perfeitamente integrado no ambiente, cercado de concubinas melanodermes, alacremente reconhecendo como legítima e cristianizando toda a numerosa descendência. O que, pelo contrário, vemos a todo o instante (e contra isso se têm insurgido numerosas autoridades) é o repúdio dos filhos espúrios havidos de aborígenes. Igualmente nos parece que certa hipertrofia do sexual, própria da cultura portuguesa, está a produzir efeitos perniciosos.

Acresce que todos temos observado que os melanodermes, quando em posições de mando, talvez vitimados pelos mesmos mecanismos psicológicos que operam no europeu de baixa extracção, são mais inclinados a condutas intolerantes para com o aborígene. Este, por sua vez, sente maior relutância em obedecer-lhes. Os conflitos revelados por esta e outras atitudes não escaparam a George Balandier que os sintetizou admiravelmente deste modo: "o compromisso racial, eles (os mistos) de nenhum modo constituem um compromisso social. Dificilmente se pode ver neles um instrumento de ligação entre a sociedade colonizada e a sociedade colonial”. Assim, em razão da sua superior condição económica e social, em razão da sua mais próxima integração no grupo dominante, estão - com excepção de certos intelectuais - mais em conflito do que em acordo com a sociedade colonizada.

E se aprofundarmos essa questão tão delicada das relações de trabalho, que diferença entre as presentes circunstâncias e a técnica do séc. XV de incorporação de escravos de cor, como afilhados, a famílias de que alguns tomavam, além do nome e da fé, modos e comportamentos, até se tornarem iguais a indivíduos livres!

E por hoje cremos ter dito o bastante para provar quão grande é a distância que separa a conjuntura sociológica moçambicana (aberrante para todos os que 
crêem na possibilidade da aplicação prática do "luso-tropicalismo") dos princípios dessa doutrina.

Será possível reconduzir o português de Moçambique às excelências do "luso-tropicalismo" por meio de técnicas de propaganda acústica e visual, como pretende Jorge Dias? Será que os ingredientes que geraram a situação sociológica designada por "luso-tropicalismo" foram sobrepujados pelos factores económicos, então dela ausentes, e que tão grande preponderância têm na civilização mecânica e aquisitiva dos dias presentes? Será que o caso moçambicano comprova a tese de Mannoni, segundo a qual a oposição entre raças não é um fenómeno primário e espontâneo, mas que se forma progressivamente, por uma evolução?

Como estudante de antropologia que somos - e, portanto, particularmente interessados na observação das culturas tradicionais nativas e suas mutações não pretendemos com estas considerações invadir o domínio duma disciplina que, embora afim, constitui hoje em dia uma especialidade distinta. Quizemos tão somente apresentar o testemunho de alguém que tem vivido em toda a sua intensidade a "situação colonial" moçambicana.

Tenham pelo menos estes debates a vantagem de mostrar a muitos que a conjuntura sociológica moçambicana não é tão singela e inócua como parece, de, enfim, suscitar certa efervescência nos espíritos. Luz completa só inquéritos profundos, feitos por sociólogos qualificados, a podem conseguir. Até lá continuemos a discutir desabaladamente, é certo que sem chegar a acordo, mas revelando, pelo menos, quão profundamente nos encontramos divididos.

Muita gente discordará das observações que fizemos. Foram elas tecidas ao redor de problemas cadentes, quase impossíveis de discutir com fleuma. As reacções de todos os que se pronunciaram, embora por vezes nos tenham causado mágoa, não nos surpreenderam, acostumados como estamos a ver os ânimos em ebulição, sempre que se cai na discussão oral da "política indígena". A “política indígena”, tenha-se em mente, é, em primeiro lugar e principalmente, uma POLÍTICA e, como tal, pasto das mais divergentes opiniões.

O maior perigo está em continuar a alimentar-nos de mitos e a admirar beatificamente, sem comentários nem reflexão, o breviário do "luso-tropicalismo". A contribuição de Jorge Dias deve considerar-se, quiçá, como o primeiro trabalho que estuda, à luz duma disciplina científica, a "situação colonial" moçambicana. Decerto que merece apoio e continuação, porque ajuda a atingir o fim que podemos resumir assim: "Conhecer a realidade para ficar apto a encontrar para ela soluções autênticas”. Análises como a que fez são também proveitosas porque, para já, nos obrigam a sérios exames de consciência, nos fazem reflectir na grave responsabilidade que sobre nós pesa: conseguir um Moçambique onde nossos filhos possam viver sem angústia. 


\section{BIBLIOGRAFIA}

ANDRADE, Mário Pinto de [sob pseudónimo de Buanga Fele], 1955, "Qu'est-ce que le lusotropicalismo?", Présence Africaine, 4-5: 24-35.

BALANDIER, Georges, 1951, "La situation coloniale: approche théorique", Cahiers Internationaux de Sociologie, 5 1: 44-79.

BOXER, Charles, 1963, Race Relations in the Portuguese Colonial Empire. Oxford, Oxford University Press.

CASTELO, Cláudia, 1999, "O Modo Português de Estar no Mundo": O Luso-tropicalismo e a Ideologia Colonial Portuguesa (1933-1961). Porto, Edições Afrontamento.

CASTElo, Cláudia, 2007, Passagens para África: O Povoamento de Angola e Moçambique com Naturais da Metrópole. Porto, Edições Afrontamento.

CASTELO, Cláudia, 2017, "The Luso-tropicalist message of the Portuguese late colonial empire”, em José Luís Garcia, Chandrika Kaul, Filipa Subtil e Alexandra Dias Santos (orgs.), Media and the Portuguese Empire. Cham, Palgrave Macmillan, 69-86.

DIAS, Jorge, 1958, "Contactos de cultura", in Centro de Estudos Políticos e Sociais, Colóquios de Política Ultramarina Internacionalmente Relevante. Lisboa, CEPS-JIU, 55-82.

DOMINGOS, Nuno, 2013, "A desigualdade como legado da cidade colonial: racismo e reprodução de mão-de-obra em Lourenço Marques”, em Nuno Domingos e Elsa Peralta (orgs.), Cidade e Império: Dinâmicas Coloniais e Reconfigurações Pós-Coloniais. Lisboa, Edições 70, 59-112.

FREYRE, Gilberto, 1933, Casa-Grande \& Senzala. Rio de Janeiro, Maia \& Schmidt Ltda.

FREYRE, Gilberto, 1953, Um Brasileiro em Terras Portuguesas: Introdução a Uma Possível Lusotropicologia Acompanhada de Conferências e Discursos Proferidos em Portugal e em Terras Lusitanas e Ex-lusitanas da Ásia, da África e do Atlântico. Rio de Janeiro, José Olympio.

HARRIS, Marvin, 1959, "Labour emigration among the Moçambique Thonga: cultural and political factors", Africa: Journal of the International African Institute, 29 (1): 50-66.

KARDINER, Abram, e Ralph LINTON, 1939, The Individual and His Society: the Psychodynamics of Primitive Social Organization. Nova Iorque, Columbia University Press.

KARDINER, Abram, et al., 1945, The Psychological Frontiers of Society. Nova Iorque, Columbia University Press.

LINTON, Ralph, 1945, The Cultural Background of Personality. Nova Iorque, Appleton-Century Crofts.

MACAGNO, Lorenzo, 1999, "Um antropólogo norte-americano no 'mundo que o português criou': relações raciais no Brasil e Moçambique segundo Marvin Harris”, Lusotopie, 6: 143-161.

MACAGNO, Lorenzo, 2002, "Lusotropicalismo e nostalgia etnográfica: Jorge Dias entre Portugal e Moçambique”, Afro-Ásia, 28: 97-124.

MACAGNO, Lorenzo, 2015, "Trabalhadores moçambicanos na África do Sul: bastidores da controvérsia entre Marvin Harris e António Rita-Ferreira", Africana Studia, 25 (2): 83-102.

MACAGNO, Lorenzo, 2016, "The birth of cultural materialism? A debate between Marvin Harris and António Rita-Ferreira", Vibrant: Virtual Brazilian Anthropology, 13 (1), disponível em < http://www.vibrant.org.br/issues/lastest-issue-v-13-n-1-01-062016/lorenzo -macagno-the-birth-of-cultural-materialism-a-debate-between-marvin-harris-and-anto nio-rita-ferreira/ > (última consulta em junho de 2019). 
MANNONI, Octave, 1950, Psychologie de la Colonisation. Paris, Seuil (edição inglesa: 1956, Prospero and Caliban: The Psychology of Colonization, Londres, Methuen).

MITCHell, Clyde, 1956, The Yao Village: A Study in the Social Structure of a Malawian Tribe. Manchester, Manchester University Press.

PELS, Peter, e Oscar SALEMINK, 1994, "Introduction: five theses on ethnography as colonial practice", History and Anthropology, 8 (1-4): 1-34.

PEREIRA, Rui Mateus, 1986, "Ideologia e mudança de estrutura social entre os Tsonga de Moçambique: um olhar crítico sobre os critérios utilizados no estudo dos factores da migração laboral no Sul do Save", Ethnologia, 3-4: 175-216.

PEREIRA, Rui Mateus, 2001, "A 'Missão etognósica de Moçambique': a codificação dos 'usos e costumes indígenas' no direito colonial português. Notas de Investigação”, Cadernos de Estudos Africanos, 1: 125-177.

PEREIRA, Rui Mateus, 2005, Conhecer para Dominar: O Desenvolvimento do Conhecimento Antropológico na Política Colonial Portuguesa em Moçambique, 1926-1959. Lisboa, Universidade Nova de Lisboa, dissertação de doutoramento em Antropologia.

PEREIRA, Rui Mateus, 2016, "Recortar, dividir, segmentar: saberes coloniales y su extensión poscolonial en Mozambique”, Revista de Antropología Social, 25 (2): 341-360.

RITA-FERREIRA, António, 2013, "António Rita-Ferreira (depoimento, 2012)”, Lisboa, IICT, transcrição disponível em < http://actd.iict.pt/view/actd:MOARF > (última consulta em junho de 2019).

SAADA, Emmanuelle (org.), 2002, "Regards croisés: transatlantic perspectives on the colonial situation", French Politics, Culture and Society, 20 (2): 1-3.

SCHNEIDER, Alberto Luiz, 2013, "Charles Boxer (contra Gilberto Freyre): raça e racismo no império português ou a erudição histórica contra o regime salazarista”, Estudos Históricos, 26 (52): 253-273.

SOBRAL, José Manuel, 2007, "O outro aqui tão próximo: Jorge Dias e a redescoberta de Portugal pela antropologia portuguesa (anos 70-80 do século XX)", Revista de História das Ideias, 28: 479-526.

STOCKING, JR., George W., 1991, “Colonial situations”, em George W. Stocking, Jr. (org.), Colonial Situations: Essays on the Contextualization of Ethnographic Knowledge. Wisconsin e Londres, Wisconsin University Press, 3-9. 